\title{
FILTH FLY (DIPTERA) OVIPOSITION AND LARVAL DEVELOPMENT IN POULTRY MANURE OF VARIOUS MOISTURE LEVELS
}

\author{
Sukarsih Fatchurochim ${ }^{1}$, C. J. Geden ${ }^{2}$, and R. C. Axtell \\ Department of Entomology \\ North Carolina State University \\ Raleigh, NC 27695-7613 \\ (Accepted for publication 24 October 1988)
}

\begin{abstract}
Oviposition by four species of muscid flies on poultry manure having six levels of moisture in the range of $40-90 \%$ was compared using caged populations of adults. Musca domestica L., Muscina stabulans (Fallén), Fannia femoralis (Stein) and Ophyra aenescens (Wiedemann) deposited more than $50 \%$ of their eggs in manure having $70 \%$ moisture. Eggs from those fly species and two others, Fannia canicularis (L.) and a stratiomyid, Hermetia illucens (L.), were added to poultry manure having eight levels of moisture in the range of 20$90 \%$, and the development and size of emerging adults determined. None of the species developed in manure with 80 and $90 \%$ moisture. Development was mostly in the manure with 40-70\% moisture, although some development in drier manure occurred with $F$. canicularis and $H$. illucens. For some species there were differences in the survival of fly immatures, development time, and size of the adult flies reared in manure of different moisture levels.
\end{abstract}

Key Words: house fly, filth fly, Musca domestica, Fannia femoralis, Fannia canicularis, Muscina stabulans, Ophyra aenescens, Hermetia illucens, manure, moisture, Diptera, Muscidae, Stratiomyidae

J. Entomol. Sci. 24(2): 224-231 (April 1989)

\section{INTRODUCTION}

Several species of filth flies commonly oviposit and develop in animal manure, especially in confined animal production facilities such as used for poultry, and constitute a serious pest problem (Anderson and Poorbaugh 1964a b; Anderson 1966; Greenberg 1971; Skidmore 1985; Axtell 1986a; and references therein). The major filth fly pest in and around poultry facilities is the house fly, Musca domestica L. (Diptera: Muscidae). Other common species are Muscina stabulans (Fallén), Fannia canicularis (L.), Fannia femoralis (Stein), Ophyra aenescens (Wiedemann) (Diptera: Muscidae) and Hermetia illucens (L.) (Diptera: Stratiomyidae).

Control of the house fly and other filth flies breeding in poultry manure depends on an integrated program using cultural, biological and chemical methods (Axtell 1986b). Cultural control is based on management of the manure which should be kept as dry as possible to reduce fly oviposition and larval survival. Although there are many reports on fly oviposition and development in different kinds of animal manure, there are suprisingly few data (mostly scattered observations and anecdotes) on the effects of moisture per se in the manure (West 1951; Hart 1963; Anderson 1966; Greenberg 1971; Muenzel 1981; Skidmore 1985).

\footnotetext{
${ }^{1}$ Present address: Research Institute for Animal Disease, Bogor, Indonesia.

${ }^{2}$ Present address: Department of Entomology, Cornell University, Ithaca, NY 14853
} 
The effective use of manure management in filth fly IPM (integrated pest management) programs requires an understanding of the effects of moisture on the relative attractiveness and suitability of manure for fly oviposition and development. We conducted standardized experiments to compare the effects of various levels of manure moisture on several of the filth fly species commonly found in poultry manure.

\section{MATERIALS AND METHODS}

Flies used in the experiments were from colonies established from several hundred individuals of each species collected in poultry houses in the vicinity of Raleigh, NC. The exception was Hermetia illucens, which was not colonized. Recently deposited eggs of this species were collected from silage near Raleigh. The approximate age of the fly colonies at the beginning of the experiments was 9 months for the house fly and 3 months for the other species. The fly colonies were maintained at $26 \pm 1^{\circ} \mathrm{C}$ with water, milk and sugar provided for the adults; larval development was in a mixture of dry fly medium (CSMA medium, Ralston Purina Co., St. Louis, MO), brewer's yeast and water.

Poultry manure used in the experiments was collected on boards suspended beneath caged laying hens (White Leghorn, HyLine) for $24 \mathrm{hr}$ periods and partially air-dried outdoors on a screen-wire platform. The birds received a standard $18 \%$ protein laying mash diet containing corn, poultry meal, soybean meal, limestone, vitamins, trace minerals, phosphate, salt and choline, but no medications. After air-drying, the mean moisture content of the manure was determined by totally drying samples of the manure in an oven. The proportion of water in the air-dried manure was calculated by $(\mathrm{A}-\mathrm{T}) \div \mathrm{A}$, where $\mathrm{A}=$ grams of air-dried sample, and $\mathrm{T}=$ grams of the sample after totally drying in the oven. Water was added to the air-dried manure to obtain the various moisture levels in the manure used in the experiments. The grams of water (X) to be added to each 100 grams of air-dried manure to obtain a desired moisture content was calculated from the formula: $\mathrm{X}=\frac{(\mathrm{Y})(\mathrm{D})}{1-\mathrm{Y}}-\mathrm{C}$, where $\mathrm{Y}=$ desired proportion of water in the manure, $\mathrm{D}=$ ovendried weight of $100 \mathrm{~g}$ of the air-dried manure, and $\mathrm{C}=$ grams of water in $100 \mathrm{~g}$ of the air-dried manure. We used this procedure of adding water to the air-dried manure because the physical characteristics of the manure were maintained in a more natural state than if we used the alternative of adding water to oven-dried manure.

\section{Manure Moisture Versus Oviposition}

Six levels of moisture content in poultry manure were used: 40, 50, 60, 70, 80 and $90 \%$. There were two cups (ca. $100 \mathrm{cc}$ manure in $120 \mathrm{cc}$ plastic cups, $6 \mathrm{~cm}$ diam. $\times 7 \mathrm{~cm} \mathrm{ht.)} \mathrm{of} \mathrm{manure} \mathrm{for} \mathrm{each} \mathrm{moisture} \mathrm{level.} \mathrm{The} 12$ cups were randomly placed in a circle in a screen cage $(1 \times 1 \times 1 \mathrm{~m})$ with water and granular sugar in the center of each cage. The cages were in an enclosed poultry rearing room with fan ventilation and a temperature range of $20-30^{\circ} \mathrm{C}$ with continuous incadescent light. Each cage contained 250 female and 100 male flies with dead flies replaced daily to maintain a constant number and sex ratio during the experiment. After 8 $\mathrm{hr}$ of exposure (ca. 1000-1800 hr), the cups of manure were removed. This short exposure time was insufficient for the fly eggs to hatch (confirmed by observations). The experiment was repeated using freshly prepared cups of manure on 3 
consecutive days. There were four cages for each of the following fly species: $M$. domestica, M. stabulans, $F$. femoralis and $O$. aenescens.

After exposing the cups of manure for oviposition, either water or dry manure was added to each cup to adjust all of them to ca. $75 \%$ moisture in order to provide uniform conditions for egg hatch and larval development. After holding the cups for 2 days at $27^{\circ} \mathrm{C}$, the larvae (second stage) were extracted from each cup of manure into $80 \%$ alcohol by means of Tullgren funnels. Previous tests of these funnels showed $90-100 \%$ recovery of fly larvae (Axtell 1966). The number of larvae recovered per cup $(n=24)$ for each moisture level was used as an indicator of the number of eggs deposited. The percent of the total number of eggs deposited on the manure of the various moisture levels were used in ANOVA and significant differences $(P \leq 0.05)$ among the means determined using Duncan's (1955) multiple range test.

\section{Manure Moisture Versus Larval Development}

Poultry manure at eight levels of moisture was used: 20, 30, 40, 50, 60, 70, 80 and $90 \%$. The manure was held in plastic cups $(340 \mathrm{cc}, 8 \mathrm{~cm} \mathrm{diam} . \times 10.5 \mathrm{~cm} \mathrm{ht}$.) with five cups for each moisture level. After adding 50 fly eggs to each cup of manure and adding a cloth mesh lid, the cups were held at $26.6^{\circ} \mathrm{C}(50-70 \% \mathrm{RH})$ until adult emergence was completed. Fly eggs were less than $4 \mathrm{hr}$ old at the time of introduction, except for the eggs of $H$. illucens which were field-collected and of undetermined age. Each cup was weighed every 2 days and sufficient water added to maintain the initial weight and moisture level. Adult flies were removed daily from the cups and counted to obtain the number of days for development from egg to adult. The total numbers of adult flies produced per cup from the 50 eggs were used to express the survival at the various moisture levels. Development time and total number of flies produced per cup were analyzed by ANOVA and significant differences $(\mathrm{P} \leq 0.05)$ among the means determined using Duncan's (1955) multiple range test. In addition, possible effects of manure moisture on the size of the adult flies were examined by morphometric measurements (maximum width of the head viewed dorsally and dry weight after holding in oven at $38^{\circ} \mathrm{C}$ for 3 days) of a random sample of 25 females emerged from each moisture level. This experiment was conducted for the following six species: $M$. domestica, $M$. stabulans, $F$. femoralis, $F$. canicularis, $O$. aenescens, and $H$. illucens.

\section{RESULTS AND DISCUSSION}

The moisture content of the poultry manure clearly affected the choice of oviposition sites by the four species of flies included in the experiment (Table 1). Most of the oviposition was in the manure having $70 \%$ moisture while a lesser, but substantial, amount of oviposition was in manure having $60 \%$ moisture. Very little oviposition occurred in manure with higher or lower moisture levels.

Ophyra aenescens was most discriminating with $86 \%$ of its eggs laid in the manure having $70 \%$ moisture. The house fly, $M$. domestica, was nearly as discriminating with $76 \%$ of its eggs laid in the manure having $70 \%$ moisture. Muscina stabulans laid $69 \%$ of its eggs in the manure having $70 \%$ moisture. The least discriminating was $F$. femoralis with 51,25 and $11 \%$ of its eggs laid in manure having 70, 60 and $50 \%$ moisture, respectively. 
Table 1. Mean ( \pm SE) percent of total number of eggs depostied on poultry manure of differing moisture content (40-90\% w/w) by four species of flies.

\begin{tabular}{|c|c|c|c|c|c|c|c|}
\hline \multirow[b]{2}{*}{ Fly species } & \multirow{2}{*}{$\begin{array}{l}\text { Total } \\
\text { number } \\
\text { of eggs }\end{array}$} & \multicolumn{6}{|c|}{ Manure moisture content (\%)* } \\
\hline & & 40 & 50 & 60 & 70 & 80 & 90 \\
\hline Musca domestica & 2845 & $0.5 \pm 0.2 \mathrm{c}$ & $4.0 \pm 1.2 \mathrm{c}$ & $13.0 \pm 3.2 \mathrm{~b}$ & $76.5 \pm 3.6 \mathrm{a}$ & $5.7 \pm 2.2 \mathrm{c}$ & $0.3 \pm 0.3 \mathrm{c}$ \\
\hline Muscina stabulans & 735 & $3.2 \pm 1.6 \mathrm{c}$ & $5.2 \pm 1.3 \mathrm{c}$ & $17.0 \pm 3.9 \mathrm{~b}$ & $69.3 \pm 4.7 \mathrm{a}$ & $3.7 \pm 1.1 \mathrm{c}$ & $1.6 \pm 0.3 \mathrm{c}$ \\
\hline Fannia femoralis & 870 & $1.1 \pm 0.5 \mathrm{~d}$ & $11.1 \pm 2.4 \mathrm{c}$ & $25.9 \pm 3.3 \mathrm{~b}$ & $51.5 \pm 4.9 \mathrm{a}$ & $8.0 \pm 2.3 \mathrm{~cd}$ & $2.4 \pm 0.5 \mathrm{~cd}$ \\
\hline Ophyra aenescens & 562 & $0.2 \pm 0.1 \mathrm{~b}$ & $1.0 \pm 0.7 \mathrm{~b}$ & $7.2 \pm 4.1 \mathrm{~b}$ & $86.6 \pm 5.6 \mathrm{a}$ & $4.7 \pm 3.1 \mathrm{~b}$ & $0.3 \pm 0.2 \mathrm{~b}$ \\
\hline
\end{tabular}

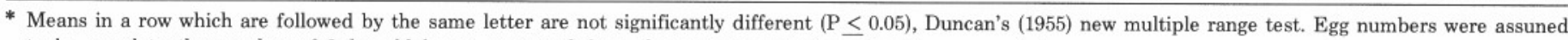
to be equal to the number of 2-day-old larvae extracted from the manure containers ( $\mathrm{n}=24$ per species). 
Table 2. Mean ( \pm SE) number of adults produced from 50 eggs/container $(n=5)$, days for development from egg to adult, and adult size (weight and head width of females, $n=25$ ) of six species of flies reared in poultry manure of differing moisture content $(20-90 \% \mathrm{w} / \mathrm{w})$ at $26.6^{\circ} \mathrm{C}$.

\begin{tabular}{|c|c|c|c|c|c|c|c|c|c|c|c|c|c|c|c|c|}
\hline \multirow{2}{*}{$\begin{array}{l}\text { Fly species } \\
\& \text { parameter }\end{array}$} & \multicolumn{16}{|c|}{ Manure moisture content $(\%)^{*}$} \\
\hline & 20 & 30 & & 40 & & & 50 & & & 60 & & & 70 & & 80 & 90 \\
\hline Musca domestica & $0.0 \mathrm{c}$ & $0.0 \mathrm{c}$ & 17.0 & \pm 4.0 & b & 40.6 & \pm 1.2 & a & 45.4 & \pm 2.8 & $\mathbf{a}$ & 43.2 & \pm 0.6 & $\mathrm{a}$ & $0.0 \mathrm{c}$ & $0.0 \mathrm{c}$ \\
\hline No. adults from 50 eggs & -- & -. & 14.0 & \pm 0.3 & a & 13.0 & \pm 1.1 & a & 13.2 & \pm 0.1 & a & 13.3 & \pm 0.1 & a & -- & -. \\
\hline Days to adult emergence & -- & -- & 2.06 & \pm 0.09 & d & 3.00 & \pm 0.07 & $\mathrm{c}$ & 3.32 & \pm 0.05 & $\mathrm{~b}$ & 3.71 & \pm 0.12 & a & -- & -- \\
\hline $\begin{array}{l}\text { Dry weight, mg } \\
\text { Head width, mm }\end{array}$ & -- & -- & 2.09 & \pm 0.02 & $\mathrm{~d}$ & 2.32 & \pm 0.02 & $\mathrm{c}$ & 2.39 & \pm 0.02 & $\mathrm{~b}$ & 2.49 & \pm 0.01 & $\mathrm{a}$ & -- & -- \\
\hline Muscina stabulans & $0.0 \mathrm{e}$ & $0.0 \mathrm{e}$ & 5.6 & \pm 2.2 & $\mathrm{~d}$ & 18.0 & \pm 1.5 & c & 23.6 & \pm 3.2 & $\mathrm{~b}$ & 33.8 & \pm 2.0 & a & $0.0 \mathrm{e}$ & $0.0 \mathrm{e}$ \\
\hline No. adults from 50 eggs & -- & -- & 16.7 & \pm 0.8 & $\mathrm{~b}$ & 18.3 & \pm 0.1 & a & 16.6 & \pm 0.3 & $\mathrm{~b}$ & 16.6 & \pm 0.1 & $\mathrm{~b}$ & -- & -- \\
\hline Days to adult emergence & -- & -- & 3.14 & \pm 0.15 & d & 4.62 & \pm 0.10 & c & 5.05 & \pm 0.08 & $\mathrm{~b}$ & 5.58 & \pm 0.12 & $a$ & -- & -. \\
\hline $\begin{array}{l}\text { Dry weight, } \mathrm{mg} \\
\text { Head width, } \mathrm{mm}\end{array}$ & -- & -- & 2.33 & \pm 0.03 & d & 2.43 & \pm 0.01 & $\mathrm{c}$ & 2.52 & \pm 0.02 & $\mathrm{~b}$ & 2.62 & \pm 0.02 & a & -- & -- \\
\hline Fannia femoralis & $0.0 \mathrm{~b}$ & $0.0 \mathrm{~b}$ & 38.2 & \pm 2.7 & a & 40.6 & \pm 2.2 & $\mathrm{a}$ & 38.4 & \pm 2.1 & $\mathrm{a}$ & 41.0 & \pm 1.3 & a & $0.0 \mathrm{~b}$ & $0.0 \mathrm{~b}$ \\
\hline No. adult from 50 eggs & -- & -- & 18.6 & \pm 2.1 & a & 16.1 & \pm 0.1 & a & 15.6 & \pm 1.6 & $\mathrm{a}$ & 15.1 & \pm 0.4 & $\mathrm{a}$ & -. & -- \\
\hline Days to adult emergence & -- & -. & 0.65 & \pm 0.02 & d & 0.93 & \pm 0.03 & $\mathrm{c}$ & 1.25 & \pm 0.05 & $\mathrm{~b}$ & 1.37 & \pm 0.04 & $a$ & -- & -- \\
\hline $\begin{array}{l}\text { Dry weight, mg } \\
\text { Head width, mm }\end{array}$ & -. & -. & 1.11 & \pm 0.04 & c & 1.34 & \pm 0.01 & b & 1.52 & \pm 0.01 & $a$ & 1.55 & \pm 0.01 & $\mathrm{a}$ & - & - \\
\hline
\end{tabular}


Fannia canicularis

No. adults from 50 eggs

Days to adult emergence

Dry weight, mg

Head width, mm

\section{Ophyra aenescens}

No. adults from 50 eggs

Days to adult emergence

Head width, mm

\section{Hermetia illucens}

No. adults from 50 eggs

Days to adult emergence

Dry weight, $\mathrm{mg}$

Head width, mm
Dry weight, mg

$$
\begin{array}{ccc}
0.0 \pm 0.0 \mathrm{c} & 3.8 & \pm 1.1 \quad \mathrm{c} \\
-- & 42.7 \pm 4.0 \quad \mathrm{a} \\
-- & 1.56 \pm 0.11 \mathrm{~b} \\
-- & 1.60 \pm 0.04 \mathrm{~b}
\end{array}
$$

* Means in a row which are followed by the same letter are not significantly different $(\mathrm{P} \leq 0.05)$, Duncan's 1955$)$ new multiple range test. 
Larval survival and the sizes of the emerging adults were relatd to the moisture content of the manure (Table 2). At low (20\%) and high moisture levels (80 and $90 \%$ ), there was no development of any of the species. With manure containing $30 \%$ moisture, $M$. domestica, $M$. stabulans, $F$. femoralis and $O$. anenscens did not develop while there was some development of $F$. canicularis and $H$. illucens.

The development of $M$. domestica was similar at 50,60 and $70 \%$ moisture but significantly reduced in manure with $40 \%$ moisture. The level of moisture did not affect the time for development from egg to adult but did affect adult size. The adults were significantly larger when reared in manure having $70 \%$ moisture than in drier manure. Production of M. stabulans was greatest in manure with $70 \%$ moisture and progressively less in drier manure; likewise, the size was greater for those reared in manure having $70 \%$ moisture and progressively less in drier manure. The time for development of $M$. stabulans was significantly greater when reared in manure having $50 \%$ moisture than in the manure of other moisture levels.

The two species of Fannia differed in their responses to development in manure of various moisture contents. Fannia femoralis production and development time did not differ significantly with the manure moisture levels of $40-70 \%$. The size of adult $F$. femoralis, however, was greater when reared in manure having $70 \%$ moisture and was progressively less with drier manure. Time for development of $F$. canicularis did not differ significantly with the moisture levels of $40-70 \%$ but the number of flies produced varied. Production of $F$. canicularis was significantly greater when reared in manure having 40,50 and $60 \%$ moisture than in the drier manure (30\% moisture) and the development at 40 and $50 \%$ moisture was significantly greater than at $70 \%$ moisture. The size of $F$. canicularis adults was greatest when rearing was in manure having $70 \%$ moisture but the size did not differ significantly among those reared in manure of the other moisture levels.

Ophyra aenescens production from manure having 40-70\% moisture did not differ significantly. The time for development was least with $70 \%$ moisture but did not differ significantly with the other moisture levels. Development times, however, were longer than expected probably due to the absence of prey in the manure (Johnson and Venard 1957; Anderson and Poorbaugh 1964a; Nolan and Kissam 1985; Geden et al. 1988). Adult size was greatest at the highest moisture level $(70 \%)$ and progressively decreased with drier manure.

The $H$. illucens production was greatest and did not differ significantly with manure moisture levels of $40-60 \%$. Production was significantly less in manure of $70 \%$ moisture which was surprising due to the tendency of this fly to be abundant in semi-liquified manure (Copello 1926; Booth and Sheppard 1984; Axtell and Edwards 1970; Furman et al. 1959). Development times differed slightly among the moisture levels with significantly longer times at the highest and lowest moisture levels. The size of the flies was greatest for those reared in manure having $70 \%$ moisture and was progressively less with the lower moisture levels.

These data provide a guide to the levels of manure moisture that are least conducive to fly breeding in poultry houses. It is reasonable to expect that the same relationships of fly oviposition and development to manure moisture exist for other kinds of livestock manure although additional experiments should be conducted. The amount of moisture in confined animal manure is obviously a critical factor in determining the abundance of filth flies. Because little fly oviposition and larval development would be expected in manure having less than $40 \%$ or greater than 
$80 \%$ moisture, manure management as a filth fly IPM tool would be expected to be most successful if one or the other of those moisture levels is maintained.

\section{ACKNOWLEDGMENTS}

The authors thank T. D. Edwards for assisting in the experiments. This is Paper No. 1167 of the Journal Series of the North Carolina Agricultural Research Service, Raleigh, N.C. This research was supported in part by USDA-Cooperative States Research Grant No. 86-CRSR2-2889 and by a grant from Winrock International Institute for Agricultural Development to the senior author for graduate study at North Carolina State University.

\section{LITERATURE CITED}

Anderson, J. R. 1966. Recent developments in the control of some arthropods of public health and veterinary importance. Muscoid flies. Bull. Entomol. Soc. Amer. 12: 342-48.

Anderson, J. R., and J. H. Poorbaugh. 1964a. Biological control possibility for house flies. Calif. Agric. 18(9): 2-4.

Anderson, J. R., and J. H. Poorbaugh. 1964b. Observations on the ethology and ecology of various Diptera associated with northern California poultry ranches. J. Med. Entomol. 1: 131-47.

Axtell, R. C. 1966. Comparative toxicities of insecticides to house fly larva and Macrocheles muscaedomesticae, a mite predator of the house fly. J. Econ. Entomol. 59: 1128-30.

Axtell, R. C. 1986a. Fly control in confined livestock and poultry production. Technical Monograph, Ciba-Geigy Corp., Agricultural Div., Greensboro, North Carolina [27419, USA]. 59 p.

Axtell, R. C. 1986b. Fly management in poultry production: Cultural, biological, and chemical. Poultry Sci. 65: 657-67.

Axtell, R. C., and T. D. Edwards. 1970. Hermetia illucens control in poultry manure by larviciding. J. Econ. Entomol. 63: 1786-87.

Booth, D. C., and D. C. Sheppard. 1984. Oviposition of the black soldier fly Hermetia illucens (Diptera: Stratiomyidae): Eggs, masses, timing, and site characteristics. Environ. Entomol. 13: 421-23.

Copello, A. 1926. Biologia de Hermetia illucens Latr. Rev. Soc. Entomol. Argentina 1:23-7.

Duncan, D. B. 1955. Multiple range and multiple F tests. Biometrics 11: 1-41.

Furman, D. P., R. D. Young, and E. P. Catts. 1959. Hermetia illucens (L.) in natural control of Musca domestica. J. Econ. Entomol. 52: 917-21.

Geden, C. J., R. E. Stinner, and R. C. Axtell. 1988. Predation by predators of the house fly in poultry manure: Effects of predator density, feeding history, interspecific interference, and field conditions. Environ. Entomol. 17: 320-29.

Greenberg, B. 1971. Flies and Disease. Vol. 1. Ecology, Classification and Biotic Associations. Princeton Univ. Press, Princeton, New Jersey. 856 p.

Hart, S. A. 1963. Fowl fecal facts. World's Poultry Sci. J. 19: 262-72.

Johnson, W. T., and C. E. Venard. 1957. Observations on the biology and morphology of Ophyra aenescens. Ohio J. Sci. 57: 21-6.

Muenzel, M. 1981. The occurrence and growth of flies (Diptera: Muscidae, Calliphoridae) on provisions of animal origin. Z. Angew. Zool. 68: 393-414.

Nolan, M. P. III, and J. B. Kissam. 1985. Ophyra aenescens. A potential bio-control alternative for house fly control in poultry houses. J. Agric. Entomol. 2: 192-95.

Skidmore, P. 1985. The Biology of the Muscidae of the World. W. Junk, Publishers, Dordrecht, Netherlands. 550 p.

West, L. S. 1951. The House Fly. Its natural history, medical importance, and control. Comstock Publ. Co., Ithaca, N.Y. 584 p. 